\title{
Cytochrome oxidase activity in the gastric mucosa of patients with iron deficiency
}

\author{
W. D. STONE \\ From the Department of Medicine, Queen Elizabeth Hospital, Birmingham
}

SYNOPSIS Cytochrome oxidase activity was assessed histochemically in gastric biopsies taken from? 22 iron-deficient patients. Activity was strong only in parietal cells, and the total amount of activity $-\underset{-}{-}$ appeared to be proportional to the number of parietal cells present in the sections. No evidence $\sigma_{\sigma}^{\circ}$ was found of diminished activity within parietal cells.

The epithelial changes commonly found in irondeficient patients could possibly be due to a deficiency of essential iron-containing enzymes. In gastrointestinal mucosae the effect of such a deficiency might be aggravated by the rapid turnover of cells. This hypothesis could explain the improvement in gastric secretion which has been found by several authors after the treatment of iron-deficiency anaemia (Shearman, Delamore, and Gardner, 1966; Jacobs, Lawrie, Entwhistle, and Campbell, 1966; Stone, 1968).

Cytochrome oxidase was chosen for study in the gastric mucosa because previous work (Jacobs, 1961; Dagg, Jackson, Curry, and Goldbreg, 1966) had shown that this enzyme might occasionally be absent in the buccal mucosa of iron-deficient patients.

\section{METHODS}

Gastric biopsies were taken with a Crosby-Kugler capsule (Crosby and Kugler, 1957) at a distance of 45 to $55 \mathrm{~cm}$ from the incisor teeth (Joske, Finckh, and Wood, 1955). The biopsies were flattened on a card and immediately frozen between two pieces of solid carbon dioxide. They were cut within two hours using a cooled knife at about $-30^{\circ} \mathrm{C}$. Sections of 8 to $10 \mu$ in thickness were dried in air and stained by the method of Butcher, Diengdoh, and Chayen (1964). The reagent employed was a solution of $\mathrm{N}$-phenyl-p-phenylenediamine and 1-hydroxy-2-naphthoic acid, buffered to $p \mathrm{H} \mathrm{7.4}$ with Tris buffer; the incubation period was 60 minutes. Adjacent sections were stained with haematoxylin and eosin and the degree of gastritis was assessed by the criteria of Bock, Arapakis, Witts, and Richards (1963).

Maximal acid output was studied in some patients with the histamine-infusion test (Lawrie, Smith, and Forrest, 1964). Serum iron and iron-binding capacity

Received for publication 20 February 1968. were determined by the methods of Ramsay (1957a and $\underset{\mathbb{D}}{\mathcal{C}}$ b).

PATIENTS STUDIED

Biopsies from two normal subjects and from 22 patients with iron deficiency were stained for cytochrome oxidase $\overrightarrow{0}$ activity: clinical and haematological data and a histo-ळ logical assessment of the severity of the gastritis are shown in the Table. Iron deficiency was diagnosed by theo finding of an ircn-binding capacity saturated less than $16 \%$ (Bainton and Finch, 1964). One patient (case 9)응 had a normal serum iron level and percentage saturation, but his red cells were grossly hypochromic and the anae- $\mathbb{D}$ mia, due to a carcinoma of the colon, responded rapidly $\vec{F}$ to iron. One patient (case 17) did not have a serum? iron estimation, but the anaemia was also grossly? hypochromic and responded to iron. In one patient (case 19) the haemoglobin was $13.0 \mathrm{~g} / 100 \mathrm{ml}$ despite a low serum iron and percentage saturation.

\section{RESULTS}

The distribution of enzyme activity was similar to that described by Floch, van Noorden, and Spiro (1967) in the stomachs of normal man, monkey, and chimpanzee. Activity was strong in parietal cells, $\frac{D}{0}$ and slight activity was present in chief cells, but the epithelial cells were unstained (Fig. 1). Cyto- $N$ chrome oxidase activity was virtually absent from $N$ one biopsy, from case 7 , which contained no parietal cells. In all other biopsies the intensity of the stain- $\omega$ ing of parietal cells was similar. Furthermore, alk parietal cells present appeared to be stained to $a$ similar extent. The number of these cells, and there- $\mathbb{D}$ fore the total amount of staining, varied with the severity of the atrophic change, as determined in the haematoxylin and eosin preparations. This is illus- $\overrightarrow{\mathbb{D}}$ trated by sections from a patient with atrophic $\frac{?}{\mathbb{D}}$ gastritis (Fig. 2). 


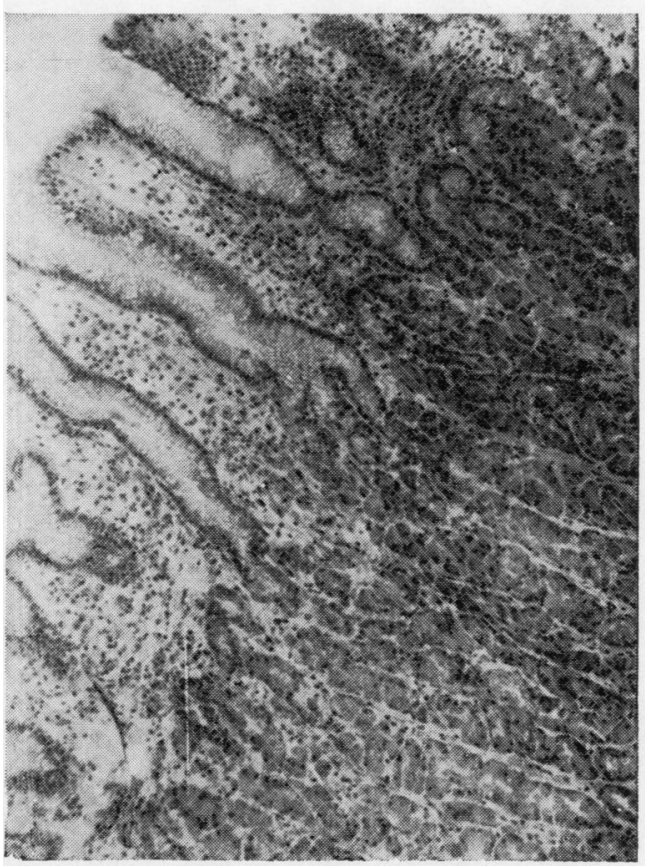

A Haematoxylin and eosin

FIG. 1. Gastric biopsy from a normal subject $(\times 100)$.

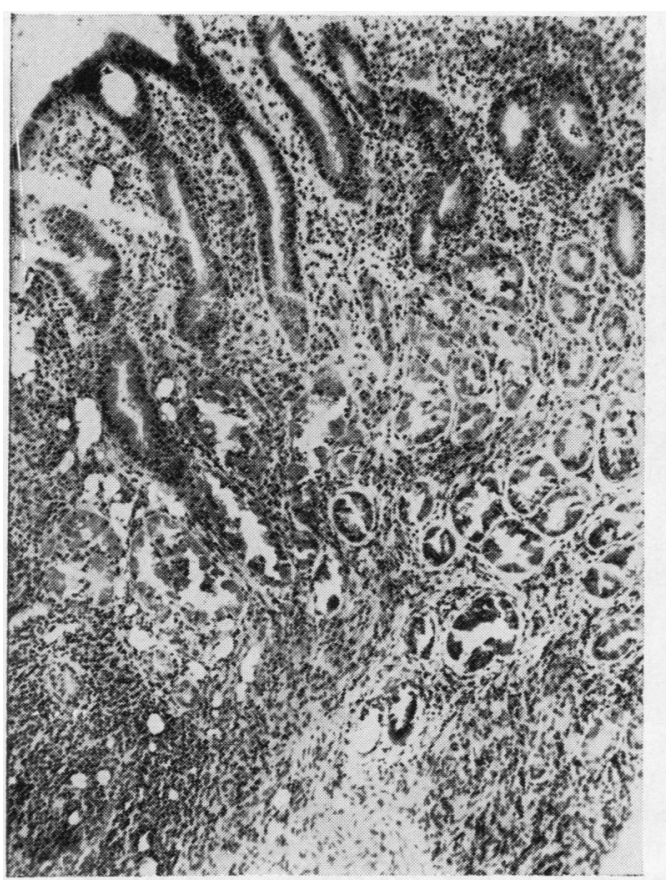

A Haematoxylin and eosin

FIG. 2. Gastric biopsy from a patient with atrophic gastritis $(\times 100)$.

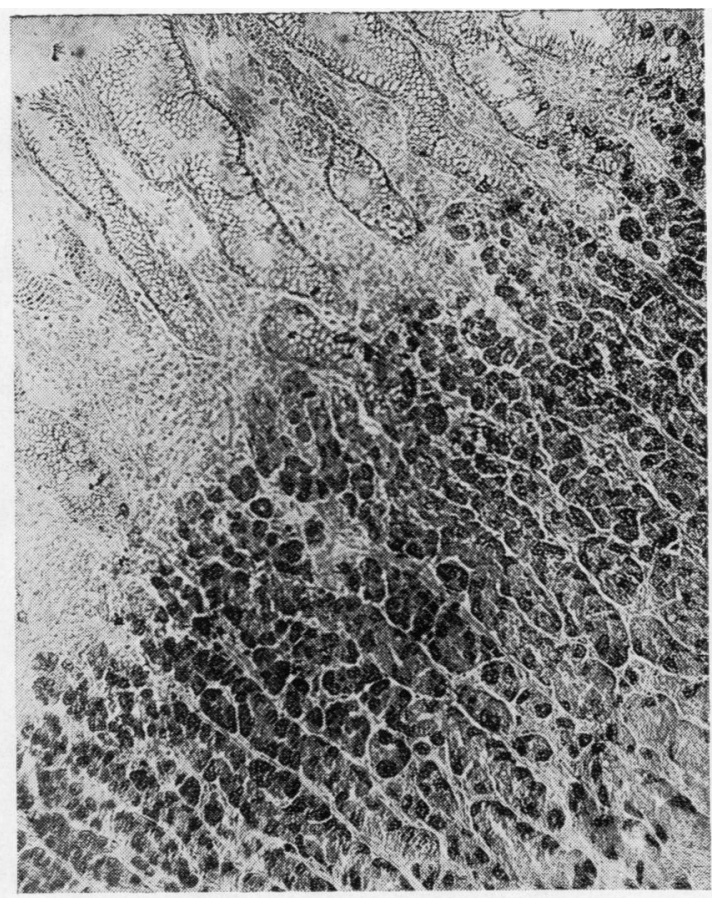

$B$ Cytochrome oxidase

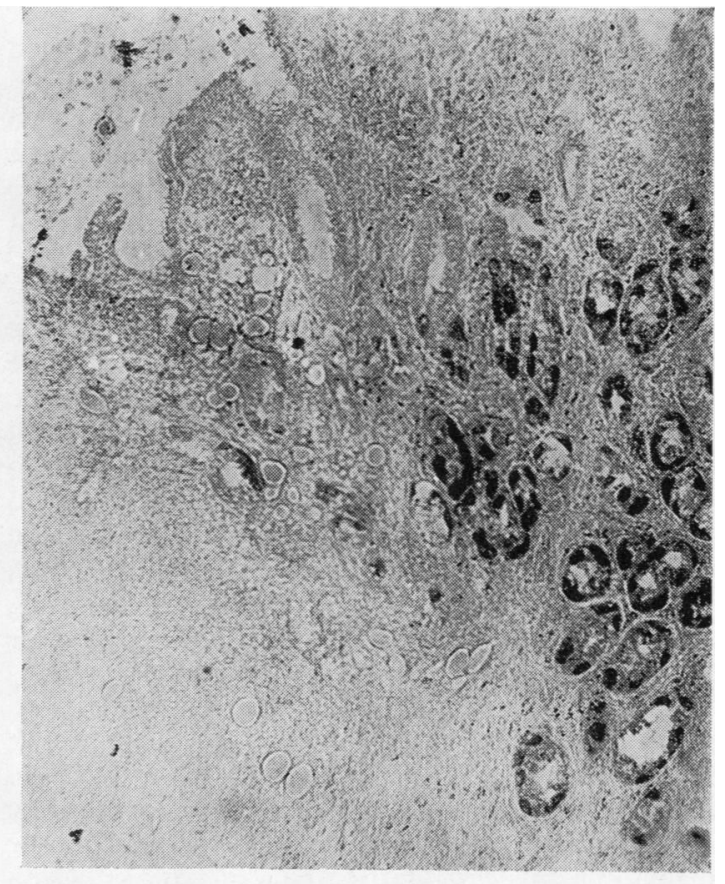

B Cytochrome oxidase 
TABLE I

DETAILS OF THE PATIENTS STUDIED

\begin{tabular}{|c|c|c|c|c|c|c|c|}
\hline Patient & Sex & Age & $\begin{array}{l}\text { Haemoglobin } \\
(\mathrm{g} / 100 \mathrm{ml})\end{array}$ & $\begin{array}{l}\text { Serum Iron } \\
(\mu \mathrm{g} / 100 \mathrm{ml})\end{array}$ & $\begin{array}{l}\text { Saturation } \\
\text { of TIBC } \\
(\%)\end{array}$ & $\begin{array}{l}\text { Maximal } \\
\text { Acid Output } \\
\text { (m-equiv) }\end{array}$ & $\begin{array}{l}\text { Histological } \\
\text { Grade }^{1}\end{array}$ \\
\hline 1 & $\mathbf{M}$ & 34 & $14 \cdot 4$ & 123 & $36 \cdot 2$ & - & $\mathbf{N}$ \\
\hline 2 & $\mathbf{M}$ & 52 & $14 \cdot 8$ & 'Normal' & - & $14 \cdot 4$ & $\mathbf{A G}$ \\
\hline 3 & $\mathbf{M}$ & 47 & 5.4 & 25 & $6 \cdot 7$ & - & $\mathbf{N}$ \\
\hline 4 & $\mathbf{M}$ & 67 & $7 \cdot 6$ & 50 & $9 \cdot 3$ & $21 \cdot 0$ & SG \\
\hline 5 & $\mathbf{F}$ & 24 & $6 \cdot 7$ & 45 & 10.0 & $34 \cdot 0$ & SG \\
\hline 7 & $\mathbf{F}$ & 38 & $7 \cdot 6$ & 13 & $2 \cdot 5$ & 0 & $\mathbf{A G}$ \\
\hline 8 & $\mathbf{F}$ & 53 & 3.6 & 105 & $15 \cdot 2$ & $8 \cdot 0$ & $\mathbf{N}$ \\
\hline 9 & $\mathbf{M}$ & 50 & $4 \cdot 4$ & 95 & $23 \cdot 8$ & - & $\mathbf{N}$ \\
\hline 10 & F & 50 & 4.4 & 80 & $11 \cdot 3$ & $2 \cdot 8$ & $\mathbf{A G}$ \\
\hline 11 & $\mathbf{M}$ & 48 & $7 \cdot 1$ & 45 & $7 \cdot 3$ & $16 \cdot 1$ & SG \\
\hline 12 & $\mathbf{F}$ & 53 & $5 \cdot 8$ & 40 & $7 \cdot 8$ & $24 \cdot 0$ & SG \\
\hline 13 & $\mathbf{F}$ & 43 & $8 \cdot 5$ & 50 & $7 \cdot 4$ & 26.9 & SG \\
\hline 14 & $\mathbf{F}$ & 54 & $10 \cdot 7$ & 25 & $7 \cdot 2$ & - & SG \\
\hline 15 & $\mathbf{F}$ & 78 & $8 \cdot 4$ & 20 & $4 \cdot 4$ & - & SG \\
\hline 17 & $\mathbf{F}$ & 63 & $9 \cdot 6$ & - & - & - & SG \\
\hline 18 & $\mathbf{F}$ & 59 & 10.9 & 25 & $9 \cdot 8$ & - & $\mathbf{A G}$ \\
\hline 19 & $\mathbf{M}$ & 50 & $13 \cdot 0$ & 40 & 8.9 & $43 \cdot 6$ & SG \\
\hline 20 & $\mathbf{F}$ & 39 & 6.5 & 15 & $2 \cdot 5$ & - & $\mathbf{N}$ \\
\hline 21 & $\mathbf{M}$ & 63 & 8.0 & 20 & $3 \cdot 2$ & 0 & $\mathbf{A G}$ \\
\hline 22 & $\mathbf{F}$ & 52 & $8 \cdot 6$ & 20 & 6.7 & - & AG \\
\hline 23 & $\mathbf{F}$ & 61 & $7 \cdot 7$ & 20 & 3.8 & - & $\mathbf{A G}$ \\
\hline 24 & $\mathbf{F}$ & 43 & $9 \cdot 3$ & 15 & - & - & $\mathbf{A G}$ \\
\hline
\end{tabular}

\section{DISCUSSION}

Previous work in animals and in man has suggested that the concentration of various cellular ironcontaining compounds may sometimes be diminished in the iron-deficient state, but no very consistent picture has emerged. Hahn and Whipple (1936) found that myoglobin was normal in iron-deficient dogs, and proposed that tissue iron was 'inviolate' when compared with haemoglobin. Waldenström (1938), however, suggested that much of the fatigue and 'adynamia' of iron-deficient patients could be related to enzyme depletion rather than to anaemia. This possiblity was tested in a double-blind trial (Beutler, Larsh, and Gurney, 1960) in patients who were not anaemic: those who were later shown to have had diminished marrow iron stores preferred iron to placebo tablets for symptomatic relief. This group did show a small mean rise in haemoglobin, and it seems improbable that tissue iron is ever significantly depleted in the absence of anaemia.

A number of individual enzymes have been studied. Cytochromes $\mathrm{b}$ and $\mathrm{c}$ were depressed in iron-deficient rats (Cohen and Elvehjem, 1934), and pigs showed a decrease in the cytochrome $\mathrm{c}$ of kidney and heart, in liver catalase, and in the myoglobin of heart and leg muscle (Gubler, Cartwright, and Wintrobe, 1957); cytochrome oxidase activity was unchanged. Beutler (1959) obtained similar results in rats and also showed a fall in the iron-containing but non-haem enzyme succinic dehy- $-\frac{D}{2}$ drogenase in kidney and heart. In rat liver, cyto- $\vec{F}$ chrome c (McCall, Newman, O'Brien, and Witts, $\frac{3}{3}$ 1962) and glucose-6-phosphate dehydrogenase (Srivastava, Zaheer, and Krishnan, 1964) were dimini=o shed.

In man cytochrome oxidase was possibly reducedo in iron-deficient white cells, but red-cell catalase ${ }_{3}^{-}$ was normal (Beutler, 1959). The activity of deltaamino-laevulinic acid dehydrase was depressed in iron-deficient erythrocytes (Rubino, Teso, and Rosetti, 1960).

Parts of the alimentary tract have been studied in man and in animals. Jacobs (1961) found that cytochrome oxidase was absent histochemically in the buccal mucosa of six of 30 iron-deficient patients and also in one 'normal' man who proved to haves a low serum iron and an MCHC of $29 \%$. Threew patients had recovered normal activity in biopsies taken 48 hours after an intravenous dose of irono No abnormality of succinic dehydrogenase activity was found in this study. Similar findings for cyto-? chrome oxidase were reported by Dagg et al (1966), 0 but they were unable to show any correlation with the atrophic changes present in the mucosa.

The activity of cytochrome $c$ in the intestina $\mathbb{B}$ 
mucosa of iron-deficient rats was diminished more than in heart and diaphragm, but less than in skeletal muscle (Dallman and Schwartz,1965a). Cytochrome oxidase was diminished in the villous epithelial cells, but increased staining appeared rapidly in the new cells arising from the crypts after iron had been given (Dallman and Schwartz, 1965b). Similar results were later reported in iron-deficient infants, but a number of experiments with intestinal absorption in iron-deficient rats failed to show any abnormality which could be ascribed to enzyme depletion (Dallman, Sunshine, and Leonard, 1967). Binder, Fischer, Thayer, Spencer, and Spiro (1966) found, on the other hand, that cytochrome oxidase and succinic dehydrogenase were histochemically normal in the gastric and intestinal mucosae of iron-deficient rats.

Succinic dehydrogenase in human gastric mucosa has been studied in resected specimens (Myren, Lygren, Skrede, and Oystese, 1963) and in biopsies (Myren, Skrede, and Torgersen, 1963), but it was not stated whether any patients were anaemic or iron deficient. These workers found that the enzyme activity was almost confined to parietal cells. The depth of staining varied somewhat, but they were unable to relate this to the maximal acid output: there was a striking relationship, however, between the number of stained parietal cells and the maximal acid output. The illustrations suggest that almost all parietal cells were stained, and the latter correlation merely supports the work of Card and Marks (1960) concerning the 'parietal cell mass'.

The present investigation was concerned with a different enzyme, but this was also confined to parietal cells. Clearly their metabolic activity is much higher than that of other mucosal components. The amount of staining in the sections appeared to be proportional to the number of parietal cells present, and there was no staining in one biopsy in which none of these cells were visible.

The intensity to which individual parietal cells were stained varied only slightly, and there was no biopsy in which the intensity was noticeably less than normal. Histochemical techniques are limited in their ability to demonstrate small differences in the concentration of an enzyme, and only major differences can be regarded as significant. None were observed, and it must be concluded that in this group of patients there was no evidence of depletion of cytochrome oxidase in the gastric mucosal cells. The reversible depression of gastric secretion associated with iron-deficiency anaemia in some patients may be due to the anaemia itself or to atrophic changes in the mucosa rather than to depletion of enzymes within the mucosal cells.

This work formed part of a thesis accepted for the degree of DM by the University of Oxford. I wish to thank Miss M. Domone for her excellent histological technique, and Professor D. Brewer for advice and for permission to use the laboratory facilities. Mr S. Gaunt took the photomicrographs, and the patients were kindly referred by Dr A. Paton.

\section{REFERENCES}

Bainton, D. F., and Finch, C. A. (1964). Amer. J. Med., 37, 62. Beutler, E. (1959). Illinois med. J., 116, 16.

, Larsh, S. E., and Gurney, C. W. (1960). Ann. intern. Med., 52, 378.

Binder, H. J., Fischer, D. S., Thayer, W. R., Jr, Spencer, R. P., and Spiro, H. M. (1966). Gastroenterology, 51, 364.

Bock, O. A. A., Arapakis, G., Witts, L. J., and Richards, W. C. D. (1963). Gut, 4, 106.

Butcher, R. G., Diengdoh, J. V., and Chayen, J. (1964). Quart. J. micr. Sci., 105, 497.

Card, W. I., and Marks, I. N. (1960). Clin. Sci., 19, 147.

Cohen, E., and Elvehjem, C. A. (1934). J. biol. Chem., 107, 97.

Crosby, W. H., and Kugler, H. W. (1957). Amer. J. dig. Dis., 2, 236.

Dagg, J. H., Jackson, J. M., Curry, B., and Goldberg, A. (1966). Brit. J. Haemat., 12, 331.

Dallman, P. R., and Schwartz, H. C. (1965a). Pediatrics, 35, 677. (1965b). J. clin. Invest., 44, 1631.

Sunshine, P., and Leonard, Y. (1967). Pediatrics, 39, 863.

Floch, M. H., Yan Noorden, S., and Spiro, H. M. (1967). Gastroenterology, 52, 230.

Gubler, C. J., Cartwright, G. E., and Wintrobe, M. M. (1957). J. biol. Chem., 224, 533.

Hahn, P. F., and Whipple, G. H. (1936). Amer. J. med. Sci., 191, 24.

Jacobs, A. (1961). Lancet, $2,1331$.

- - Lawrie, J. H., Entwhistle, C. C., and Campbell, H. (1966). Ibid., 2, 190.

Lawrie, J. H., Smith, G. M. R., and Forrest, A. P. M. (1964). Lancet, 2, 270.

McCall, M. G., Newman, G. E., O'Brien, J. R. P., and Witts, L. J. (1962). Brit. J. Nutr., 16, 305.

Myren, J., Lygren, T., Skrede, S., and Oystese, B. (1963). Gastroenterologia (Basel), 99, 169.

_., Skrede, S., and Torgersen, O. (1963). Ibid., 99, 319.

Ramsay, W. N. M. (1957a). Clin. chim. Acta, 2, 214.

- (1957b). Clin. chim. Acta, 2, 221.

Rubino, G. F., Teso, G., and Rosetti, L. (1960). Acta haemat. (Basel), 24, 300.

Shearman, D. J. C., Delamore, I. W., and Gardner, D. L. (1966). Lancet, 1, 845.

Srivastava, S. K., Zaheer, N., and Krishnan, P. S. (1964). Arch. Biochem., 105, 446.

Stone, W. D. (1968). Gut, 9, 99.

Waldenström, J. (1938). Acta med. scand., suppl., 90, 380. 